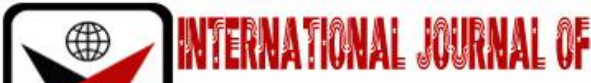

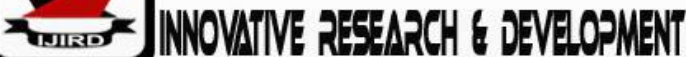

ISSN 2278-0211 (Online)

\section{Covid-19 in Nigeria: Exploring the Paradigm Shift and Issues' Arising}

\author{
Ferguson Ayemere Ehimen \\ Consultant, Department of Preventive Health Care and Community Medicine, \\ Lily Hospital, Benin City, Edo State, Nigeria \\ Omobamidele Benson Betiku \\ Consultant, Department of Family Medicine, \\ Lily Hospital, Warri, Delta State, Nigeria \\ Iboro Samuel Akpan \\ Consultant, Department of Family Medicine, \\ Lily Hospital, Benin City, Edo State, Nigeria \\ Oluwafemi Emmanuel Abidoye \\ Occupational Health Officer, Department of Occupational Health, \\ Lily Hospital, Benin City, Edo State, Nigeria \\ Ogheneruona Osawota \\ Medical IT Personnel, Department of Medicine, \\ Near East University, Turkey
}

\begin{abstract}
:
Background: Corona viruses are a family of deadly viruses that cause respiratory illnesses; they were first reported in Wuhan city, China. Since its report in China, the virus has spread almost across the whole continents of the world leading to hundreds of thousands of deaths. Furthermore, upon declaration of Covid-19 as a public health emergency of international concern, the world has moved its frontiers to new way of life viz-a-viz paradigm shifts with a cascade of issues arising on a daily basis.

Methods: The sources of the information presented was obtained through detailed review of literatures (search terms: Covid-19, Beta corona virus and paradigm shift and matter arising), anecdotal/case analysis, and surveys undertaking from the field. Also other key facts were obtained from relevant websites (such as Nigeria World health organization, Centre for Disease Control and prevention, Nigeria Center for Disease Control, Nigerian Federal Ministry of Health). Results: The likelihood of a worsened outbreak in Nigeria and other developing countries characterized by poor adherence to standard precautions, poor health care facility, deficiency of adequate laboratory facilities for prompt diagnosis and personal protective equipment (PPE) can raise the profile of this disease to worrisome levels. Regular training of health care workers, continue Covid-19 health awareness campaign, Health education of the communities, improved funding through budgetary allocation for surveillance, prompt case management including laboratory facilities, is not only extremely essential at this point in time but also expedient in the light of the threat of COVID-19.

Conclusion: The dearth of molecular laboratories and poor health-care delivery system in Nigeria would continue to impede the effective prevention and control of evolving infectious diseases including Covid-19. There is an urgent need to address all the issues impeding on Covid-19 control in order to effectively control and prevent it.
\end{abstract}

Keywords: Covid-19, Paradigm shift, Issues arising, Nigeria

\section{Introduction}

Covid-19 is a deadly viral disease caused by beta corona virus (OC43) similar to MERS-Corona virus and SARSCorona virus that causes Middle East respiratory syndrome, or MERS and Severe acute respiratory syndrome, or SARS. ${ }^{1-3}$ Covid-19was first reported in China in November/ December 2019, where a cluster of cases of pneumonia of unknown cause was seen among individuals in the city of Wuhan in Hubei province. ${ }^{4}$ In January 2020, a previously nameless new virus was now identified and named the 2019 novel coronavirus.5-6

Covid-19 is an evolving disease, the world currently battling to understand its natural history, facts are still emerging, but current information is indicating that human-to-human transmission is occurring. However, though the routes of transmission of COVID-19 remains indistinct at present, current evidence from other corona viruses and respiratory diseases indicates that the disease may spread through large respiratory droplets and direct or indirect contact with infected secretions. ${ }^{1,4,7,8}$ 
The COVID-19 pandemic in Nigeria is a piece of the worldwide pandemic of corona virus disease 2019 (COVID-19) caused by severe acute respiratory syndrome corona virus 2 (SARS-CoV-2). The first confirmed case in Nigeria was announced on 27 February 2020, when an Italian citizen in Lagos tested positive for the virus. ${ }^{9,10}$ Since then, the number of corona virus cases have increased in multiple folds in Nigeria spreading across the whole states of the federation including the Nigeria capital territory. ${ }^{11}$

Globally, As at 17thAugust, 2020, there are Twenty-one million two hundred ninety-four thousand eight hundred forty-five $(21,294,845)$ cases of Covid-19 with Seven hundred sixty-one thousand seven hundred seventy-nine(761,779) deaths, the population of Africa account for $4.4 \%$ of the total cases reported in the world. ${ }^{12}$ Of note, majority of the cases (61.8\%; 5.2\%; 4.4\%) in Africa are reported from South Africa, Nigeria and Ghana respectively. ${ }^{12}$ According to the Nigeria Centre of disease control, within same period stated above, Nigeria cases of Covid-19 have risen to forty nine thousand sixty eight $(49,068)$ cases across all states (36 states) of the federation including the Federal Capital Territory, worth mentioning as at $17^{\text {th }}$ August, 2020 , Nigeria reported discharge rate and case fatality rate was $74 \%$ and $2 \%$ respectively. ${ }^{11}$ The high discharge rate may be due to few cases now been admitted in the isolation wards, as majority of cases are now being managed at home or it may explained by improved immunity by cases and or probably due to the fact that patients are now being discharged when their symptoms resolved compare to previous discharge criteria, which entails that patient must test negative before discharge..$^{9,11,12}$

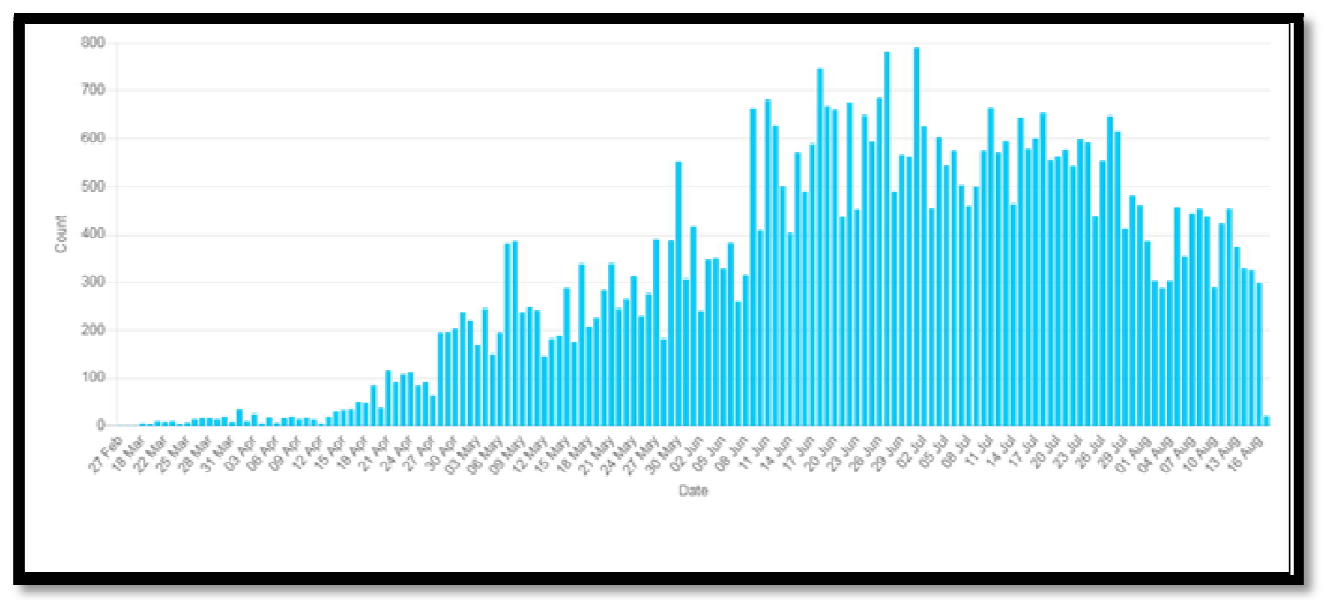

Figure 1: Epicurve of Covid-19 in Nigeria Source: $N C D C$

Despite the geometry rise in Covid-19, not all have been know about this evolving disease, as of now, researchers know that the new corona virus can spread through droplets released into the air when an infected person coughs or sneezes or when a person touches an infected surface. ${ }^{9-12}$ The droplets generally do not travel more than a few feet, and they fall to the ground (or onto surfaces) in a few seconds - this is sole motive why physical and social distancing remains one of the most successful way of preventing the spread of Covid-19.13,14Apart from the need to observe social distance at all times, other advisories have been given by World health organization (WHO) on how to remain safe as the world grapple with this pandemic, the advisories include: Regular and thorough cleaning of hands with an alcohol-based hand rub or washing with soap and water; Avoiding going to crowded places; Avoiding touching of eyes, nose and mouth with unwashed hands; Adherence to sound respiratory etiquette; public and hospital use of face masks. ${ }^{14,15}$ The sole aim of giving regular updated advisories by WHO and other relevant bodies remain the need to curtail the growing menace of Covid-19 


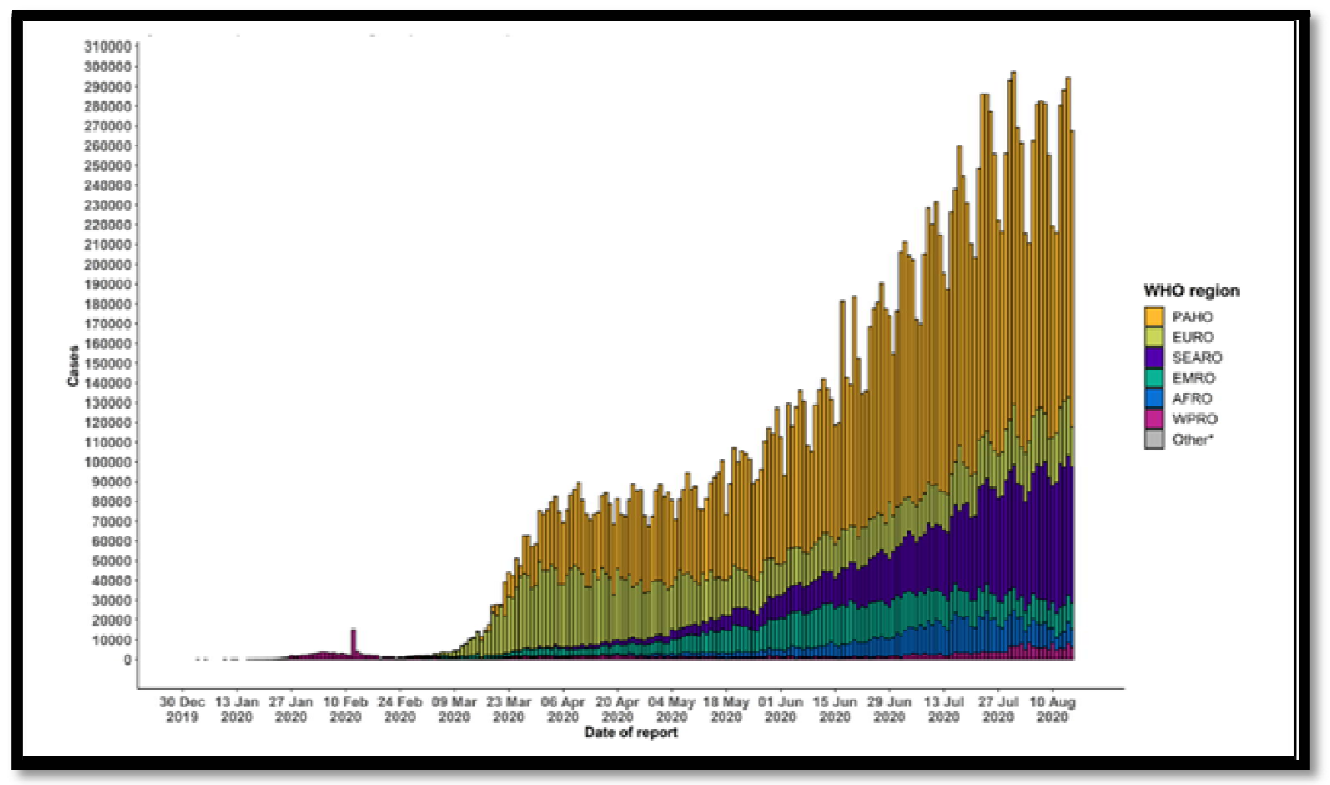

Figure 2: Epicurve of Covid-19 (Global view)

Source: WHO

\section{Paradigm Shift and Issues arising}

Paradigm Shift: 'an important change that happens when the usual way of thinking about or doing something is replaced by a new and different way'-The new normal. ${ }^{16}$ Considering the fact that we had recently experienced two epidemics with high pandemic potential, caused by two novel corona viruses: the SARS-CoV virus (2002), which infected 8000 people and killed 774 people in 26 countries, ${ }^{16,17}$ and the MERS-CoV virus (2012), which infected 2494 and killed $858 .{ }^{18}$ It would have expected that the world would have put in place shock absorber system to cushion the effect of subsequent pandemics. This was not the case, as the 2019/2020 Covid-19 pandemic has created untoward effects and mortality across nations. ${ }^{11,12}$

This paradigm change has created a profound realignment across the globe, across health industries and across populations with major change in ways of life. Since the occurrence of Covid-19 and the subsequent declaration of Covid 19 as public health emergency of international concern, 20 the world is re-adjusting to a new normal and anew future there by triggering a paradigm shift from; close contact greetings to social distance acquaintances and salutation, hospital use of face mask to community use of face mask, use of medical face masks to cloth face mask.

\section{Covid-19: From Close Contact Greetings to Social Distance Acquaintances and Salutation}

As the pandemic spread across the world, the new normal was a shift from close contact greetings to social distance acquaintances and salutation. This was particularly difficult in countries like ours and other countries of the world whose ways and culture of greeting involves handshakes, hugs and other close contact salutations. To this end, the World Health Organization and medical experts have begin to shift the concept of control of Covid-19 from social distance to physical distance, this was necessary because 'social distancing' can imply a sense of disconnection from loved ones. ${ }^{12}, 21,22$ This is dangerous considering the significant impact of Covid-19 on Mental health and the fact that being physically isolated from others can take a toll on overall well-being, hence, the reason for emphasis on physical distancing so that people can still be socially connected. This fact was reiterated on March 20 by Maria Van Kerkhove, an infectious diseases epidemiologist with the WHO, where she stated that the WHO is moving away from the term 'social distancing' to 'physical distancing' because it's important to remain physically separated but socially connected'. ${ }^{21}$ At the same time, the perceived change of terms is raising some issues, as some experts believes that changing the term in the middle of an epidemic can create confusion. Lori Peek, a sociology professor at the University of Colorado' stated that his main issue at the switch in terminology - in the midst of the pandemic - violates one of the key principles of effective risk communication, which is to ensure that there is clarity and consistency in messaging. ${ }^{21}$ Regardless of what it's called, obeying stringent guidelines on distancing and public's adherence to 'physical separation' remains one of the key factors in flattening the curve of Covid-19 and controlling of community transmission of the disease. 4, 11, 14, 20-22

Despite the central role of social distancing in Covid-19 prevention and control,11,12,22 it is disheartening to note that majority of the people in Nigeria and probably other parts of the world are beginning to show general apathy to social distance rules and guidelines. The general slackness (after initial heighten adherence to control measures) in hospital and community adherence to basic Covid-19 control measures remain very worrisome considering the rapid spread SARSCov2 virus. ${ }^{23,24}$ There is no gain saying that this general apathy will likely fuel increase in more cases of Covid-19 if nothing is done urgently to increase the level of awareness and the need to adhere to fundamental Covid-19 preventive strategies.

\section{Covid-19: Use of Face Mask and Shied-Why the Sudden Apathy?}

The act of covering the nose and mouth with face mask had been part of conventional sanitary practices against infectious diseases in early modern Europe. ${ }^{25}$ Face masks use can be principally traced back historically to a more recent period when a new understanding of contagion based on germ theory was applied to surgery as it was particularly used 
by physicians and nurses in the hospitals especially in the theatre to serve as a means of infection control during surgical procedures that involve opening up a patient's body. 25,26 However, due to the rapid emerging situation of the Covid-19, there has been a shift or more broadly a general use of facemask. ${ }^{27}$ Although, the known types of facemask that has been in use are the surgical and N95 facemasks, but the emergence of the COVID-19 pandemic has brought with it more types of facemasks including cloth facemask and others like face shield. ${ }^{27,28}$

According to World Health Organization, Universal masking in health facilities, targeted continuous and community use of face mask remains the one of the comprehensive package that will limit the spread of certain respiratory viral diseases, including COVID-19. ${ }^{29}$ However, the use of a mask alone is inadequate to provide the adequate level of protection, as complete control requires adoption of other personal and community level control measures.13, 14, 15, 29 .

All the aforementioned discussion on use of face mask and shield are laced with a lot of concerns intertwined with issues arising from such paradigm shifts. Presently, there has been a decline in the level of the use of facemasks in the general public while the numbers of infected people are increasing tremendously and the numbers of deaths are climbing. The reason for the general public laxity on the use of facemask without an alternative means of prevention is a point of concern that requires immediate attention.

Anecdotal report and observational surveys have shown a general decline in adherence to basic Covid-19 preventive strategies, this is so obvious when compared to the early stage of the Covid-19 outbreak where people were more committed to adherence measures; probably because of fear and anxiety of the unknown. This is not surprising as a report by a well know foundation published the fact that the upsurge of Covid-19 infections may be due to non-compliance to safety measures. ${ }^{30} \mathrm{In}$ its shocking revelation, it was reported that most people wear face masks because of security agents and not necessarily to prevent coronavirus spread. Also, reported was poor compliance to physical distancing directives and use of facemasks in the markets, commercial buses and most public gatherings such as wedding, burial and community meeting,'

More worrisome is the fact that majority of the people do not wear their face mask/shield. The common practice seen in the community involve; placing of face mask in the jaw, covering of only the mouth without the nose, placing of the face mask in the bag or hands. In addition, frequently seen practices include the use of face shield without face mask; this situation became so rampant that the Nigeria Centre for Disease Control had to release an advisory concerning flagrant use of face shield without face mask. It was important to advice the public on this, as the use of face shield alone (without facemask) do not offer protection against Covid-19. ${ }^{31}$

The sudden reduction and apathy in standard Covid-19 control measures is quite worrisome considering the fact that the Covid-19 cases are still increasing in a geometric proportion with associated increase in mortality. ${ }^{11,12}$ This impulsive decline and laxity in public and community adherence to basic Covid-19 control practices calls for serious public health and government intervention.

\section{Conclusion}

This article is meant to draw the attention of the world to the new normal, as paradigm shift for us to cope with Covid-19 pandemic while we address the core issues arising from paradigm change, which transcends from; close salutation to distance greetings (social distance), use of face mask at hospitals to community use. Considering the rise in Covid-19 and the dearth of infection control and community safety practices, there is expedient need for the Nigerian government and other governments of the world to focus on saving lives and livelihoods of its citizens by ensuring more Covid-19 health awareness and prevention messages get to the people daily. There is also the need to open more molecular laboratories and improve on the current health systems in order to cater for the needs of the common man. To ensure and encourage adherence to basic control practices, we advise the need for implementation of Covid-19 social welfare scheme that will provide food, basic needs and other relief materials to support those in need.

\section{References}

i. Centre for disease control and prevention. Human corona virus types. Available at https://www.cdc.gov/coronavirus/types.html. Accessed 29 July, 2020.

ii. Munster VJ, Koopmans M, Van Doremalen N, Van Riel D, de Wit E. A novel coronavirus emerging in China key questions for impact assessment. N Engl J Med. 2020

iii. Chen Y,Liu Q, GuoD. Emerging coronaviruses: genome structure, replication, and pathogenesis. JMed Virol. 2020; 92 (jmv.25681): 418-423

iv. World Health Organisation. Novel Coronavirus - China. Disease outbreak news: Update 12 January 2020.Accessed 29 July, 2020.

v. World Health Organization. Director-General's remarks at the media briefing on 2019-nCoV on 11 February 2020. 2020/2/18) [2020-02-21]. Available at https://www.who.int/dg/speeches/detail/who-directorgenerals-remarks-at-the-media-briefing-on-2019-ncov-on-11-february-2020. 2020. Accessed 29 July, 2020.

vi. Public Health England. COVID-19: epidemiology, virology and clinical features. Available from:https://www.gov.uk/government/publications/wuhan-novel-coronavirus-backgroundinformation/wuhan-novel-coronavirus-epidemiology-virology-and-clinical-features. Accessed 30 July, 2020.

vii. Physiopedia. Facts of Corona virus. Available at https://www.physio-pedia.com/Coronavirus_Disease_(COVID19) . Accessed 29 July, 2020. 
viii. Public Health England. COVID-19: epidemiology, virology and clinical features. https://www.gov.uk/government/publications/wuhan-novel-coronavirus-backgroundinformation/wuhan-novel-coronavirus-epidemiology-virology-and-clinical-features. Accessed 14 March 2020.

ix. ' 'First Case of Corona Virus Disease Confirmed in Nigeria'. Nigeria Centre for Disease Control. 28 February 2020. Retrieved 10 March 2020.

x. Maclean, Ruth; Dahir, Abdi Latif (28 February 2020). 'Nigeria Responds to First Coronavirus Case in Sub-Saharan Africa'. The New York Times. Retrieved 10 March 2020.

xi. $\quad$ Nigeria Centre for Disease Control. Available https://covid19.ncdc.gov.ng/. Accessed 29 July, 2020.

xii. World health organization. Covid-19 situation report. Available at https://www.who.int/docs/defaultsource/coronaviruse/situation-reports/20200728-covid-19-sitrep-190.pdf?sfvrsn=fec17314_2. Accessed 30 July, 2020.

xiii. Centre for disease control and prevention. Social Distancing-Keep a Safe Distance to Slow the Spread. Available at https://www.cdc.gov/coronavirus/types.html. Accessed 3 August, 2020.

xiv. World Health Organization. Coronavirus disease (COVID-19) -Advice for the public 2020. [Available from: https://www.who.int/emergencies/diseases/novel-coronavirus-2019/advice-for-public. Accessed 3 August, 2020.

xv. Centre for disease control and prevention. Consideration for wearing face mask. Available at https://www.cdc.gov/coronavirus/2019-ncov/prevent-getting-sick/cloth-face-cover-guidance.html Accessed 3 August, 2020.

xvi. Joan M. The COVID-19 Paradigm Shift-From Values to Careers to Whole Economies. Available at https://www.forbes.com/sites/joanmichelson2/2020/05/05/the-covid-19-paradigm-shift--from-values-tocareers-to-whole-economies/\#5d9872da38a2.Accessed 3 August, 2020.

xvii. Mariana CG, Elena RÁ. The COVID-19 Pandemic and Paradigm Change in Global Scientific Research. MEDICC Review, April 2020, Vol 22, No 2

xviii. $\quad$ Peiris JSM, Guan Y, Yuen KY. Severe acute respiratory syndrome. Nat Med. 2004 Nov 30;10(12 Suppl): S88-S97. 11.

xix. Al-Tawfi q JA, Memish ZA. Middle East respiratory syndrome coronavirus: Transmission and phylogenetic evolution. Trends Microbiol. 2014 Oct 22;22(10):573-9.

xx. World Health Organization. 2019-nCoV outbreak is an emergency of international concern. Available at https://www.euro.who.int/en/health-topics/health-emergencies/coronavirus-covid-

19/news/news/2020/01/2019-ncov-outbreak-is-an-emergency-of-international-concern . Accessed 3 August, 2020

xxi. Harmeet Kaur. Forget social distancing. Available at https://edition.cnn.com/2020/04/15/world/socialdistancing-language-change-trnd/index.html.Accessed 5 August, 2020.

xxii. World Health Organization. Physical distancing. Available at https://www.who.int/westernpacific/emergencies/covid-19/information/physical-distancing. Accessed 5th August, 2020.

xxiii. Centre for disease control and prevention. High Contagiousness and Rapid Spread of Severe Acute Respiratory Syndrome Coronavirus 2 Available at Available at https://www.who.int/westernpacific/emergencies/covid19/information/physical-distancing.Accessed 5 August, 2020.

xxiv. Riou J, Althaus CL. Pattern of early human-to-human transmission of Wuhan 2019 novel coronavirus (2019nCoV), December 2019 to January 2020. Euro Surveil. 2020; 25:25.

xxv. Bruno J Strasser, Thomas Schlich. A history of the medical mask and the rise of throwaway culture. Lancet. 2020 4-10 July; 396(10243): 19-20

xxvi. 26. Adams LW, Aschenbrenner CA, Houle TT, Roy RC. Uncovering the history of operating room attire through photographs. Anesthesiology. 2016; 124:19-24.

xxvii. Centres for disease control and prevention. Use of facemask in slowing down spread of Covid-19. Available at https://www.cdc.gov/coronavirus/2019-ncov/prevent-getting-sick/diy-cloth-face-coverings.html. Accessed $10^{\text {th }}$ August, 2020

xxviii. Nigeria Centre for disease control. Rational use of PPE in the care Covd-19 cases. Available at https://covid19.ncdc.gov.ng/media/files/UseOfPPEnew.pdf. Accessed 10th August, 2020

xxix. World health organization. Advice on the use of mask in the contest of Covid-19. Available at file://C:/Users/CASHIER/Downloads/WHO-2019-nCov-IPC_Masks-2020.4-eng.pdf. 10 10 August, 2020

xxx. CLEEN foundation. Covid-19: People wear face mask to avoid harassment: Available at https://prnigeria.com/2020/07/05/covid-19-face-masks-cleen/. Accessed 5 August, 2020

xxxi. AyodamolaOwoseye. Face Shields Without Masks, Not Effective in Preventing COVID-19 - NCDC. Available at https://allafrica.com/stories/202006290157.html. Accessed 5 August, 2020 